\title{
The Effects of Major Natural Disasters on Developing and Underdeveloped Countries: A look At The Savings Rate
}

\author{
Aurélien Rigolet ${ }^{1}$
}

\begin{abstract}
This paper examines the effect of natural disasters on the savings rate in developing countries. There are different theories on the effects of natural disasters on economic factors. This paper contributes to the existing literature by testing these theories through a panel data analysis. Despite the scarcity of the data, the analysis revealed tendencies in the savings behavior following natural disasters in developing countries. It shows that households first suffer from the direct effect and dig into their savings, they than increase their savings rate in order to save money to rebuild what was destroyed or damaged, and after a few years, the savings rate falls again.
\end{abstract}

\section{INTRODUCTION}

Natural disasters are becoming more frequent warns the Worldwatch Institute. Wherever they hit, they wreak havoc behind them. Every year, thousands of people are affected by storms, hurricanes, droughts, earthquakes, floods... Whether they are displaced, whether they lose their home, their work or relatives, the impacts of natural disasters on the populations are dramatic. Whereas developed economies are the one who consume most and generally produce most gas emissions, the underdeveloped and developing ones are the most severely hit by natural disasters (EM-DAT, World Map, 2009). It is thus important to wonder what the actual consequences of natural hazards on the development of underdeveloped and developing countries are.

There has been growing literature on the economic effects of natural disasters. The majority of the researches focus on their short-run effects. The long-run effects have been studied as well but less thoroughly. They are also much harder to assess. Most of the literature has focused on the purely economic effects (Noy, 2009), (Cuaresma, Hlouskova \& Obersteiner, 2008), such as economic growth and income per capita, or on the relations between economic conditions and

\footnotetext{
${ }^{1}$ Aurélien Rigolet received a bachelor degree in Economics and Business Economics at Maastricht University in 2014. At the moment, he takes a Master in Environmental Management at the Free University of Brussels. 


\section{The Effects of Major Natural Disasters}

death toll (Toya, 2007), (Padli, Habibullah \& Baharom, 2010), (Schumacher 2011), but few have focused on more precise elements of economic development.

Households are affected by hazards in many different ways. The impacts on them are often tremendous. There has been some research on the way major losses affect consumption and savings. Indeed, the consumption and savings patterns are likely to be affected. Most of the researches on the subject are case studies from which one cannot generalize. Hence, it is relevant to wonder whether or not there is a trend in the way countries are affected. Thus, this paper asks the following question: what are the effects of major natural disasters on the savings rate in developing and underdeveloped countries?

The paper starts by establishing a clear definition of what can be considered as national disasters and examines the trend in them across countries and along time. Secondly, it follows by reviewing the existing literature on the different facets of the issue, the factors that mitigate their effects, the macroeconomic and microeconomic effects and literature on the savings rate. Thirdly, the dataset used in the research is discussed. Fourthly, the methodology is briefly explained. Fifthly, an empirical analysis is conducted and interpreted. Sixthly, the limitations and the discussions opened by the research are considered before ending the paper with a concluding summary of the main findings.

\section{TRENDS IN NATURAL DISASTERS}

It is important to start by clearly defining what a natural disaster is. The definitions provided by the CRED are used as the working base for most of the academic literature on natural disasters. A disaster is a "situation or event, which overwhelms local capacity, necessitating a request to national or international level for external assistance, an unforeseen and often sudden event that causes great damage, destruction and human suffering" (EM-DAT, 2009). Disasters can either be natural or technological. Natural disasters, which comprise geophysical, meteorological, hydrological, climatological, and biological, are the center of our studies. It is important when studying them to note that although they are all beyond human control, they differ in many different features. Some are more frequent, some are more unpredictable, some are more costly to protect against.

The CRED Database makes it possible to have a look at the trend of reported natural disasters over time and the distribution around the world. There is a clear increasing trend in the number 


\section{The Effects of Major Natural Disasters}

of natural disasters reported. Whereas an increase in the reported damages is intuitive given the increase in capital accumulation along time, the increasing trend in reported natural disasters is more alarming. Natural disasters are becoming more severe and more frequent (Hoeppe, 2008). Such patterns will be a great concern for developing countries that lack adequate insurances against such disasters. Hoeppe warns that developing countries might find themselves in a "global warming trap", in which increasing ratios of development funding will be devoted to coping for the damages of natural disasters instead of fostering development.

\section{Literature Review}

The literature on hazards and their effects can be divided into 3 major subsets: the mitigating factors of natural disasters' effects; the macroeconomic effects; and the microeconomic effects. The literature on the savings rate is discussed in a separate subsection as it is especially important for the empirical analysis.

\subsection{Mitigating factors of Natural Disasters' effects}

Most of the literature on the subject is focused on the factors that limit the effects of natural disasters. Toya and Skidmore (2007), examine how the human and economic losses diminish as countries develop. They find that in addition to income, educational attainment, openness of the economy, the strength of the financial sector and the size of the government are also important factors that reduce deaths and damages. Better educational attainment, greater openness, a strong financial sector and a smaller government are correlated with lower death tolls and smaller damages. Their argument is that higher income increases the demand for safety, better education helps anticipating the disasters, a strong financial sector may reduce the effects as in a well-informed financial sector, investors are less likely to invest in inherently risky areas, greater openness is a proxy for competition and the amount of knowledge spillover from developed countries (Toya \& Skidmore, 2007). However, the model does not control for the geographic location of the countries, which is probably correlated with both the effects of the disaster and the level of development of the country. In addition, when they test the model separately for OECD countries and developing countries, they only find income as a significant estimator. 


\section{The Effects of Major Natural Disasters}

Padli, Habibullah and Baharom (2010) support the evidence that there is a significant relationship between the economic conditions of a country and the impact of natural disasters on it. They find that income is the most important determinant. Contrary to Toya \& Skidmore, Padli, Habibullah and Baharom do not find educational attainment as a significant determinant that reduces the impact of natural disasters, although the authors believe other tools could give more significant estimates. Again the model includes countries from all over the world without controlling for geography and types of natural disasters (Padli, Habibullah, \& Baharom, 2010).

Schumacher \& Strobl (2011) also focus on the relationship between wealth and the impact of natural disasters, but they bring a new insight by controlling for hazard exposure. They argue that natural disasters are not evenly spread around the world, some regions are more vulnerable to earthquakes while others are more vulnerable to cyclones, furthermore, these disasters do not all have the same properties, some are more unpredictable, some are more frequent and some are more costly than others to protect against. They find a non-linear relationship between economic losses and the level of development of a country and most importantly, they find that it depends crucially on natural hazard exposure. They find that the relationship changes depending on whether the country faces low to medium hazard exposure or if it faces high hazard exposure. The first one has a bell-shaped relationship between economic damages and wealth while the latter has a u-shaped relationship (Schumacher \& Strobl, 2011). This contradicts the first two articles that found a constantly decreasing relationship and it also adds the important insight of hazard exposure.

To sum up, the relationship between the impact of natural disasters and the level of development of a country is tricky. One does not observe a linear relationship. The level of hazard exposure has to be considered. Yet, evidence show that countries with a more efficient government, a more educated population, and higher income tend to be better armed to face natural hazards.

\subsection{MACROECONOMIC CONSEQUENCES}

Noy (2009) examines two different issues in his paper. On the one hand, it discusses the factors that mitigate the effects of natural disasters as in the articles from Toya \& Skidmore (2007) and Padli, Habibullah \& Baharom (2010). It corroborates their view that better education, better institutions, more openness and higher income are related with smaller damages from natural disasters. On the other hand, the second part of the article focuses on the macroeconomic 


\section{The Effects of Major Natural Disasters}

consequences of natural disasters. It finds that natural disasters have a significant impact on GDP growth through the amount of property damages incurred but not through the number of people killed or affected. The explanation is that losses in property immediately affect GDP growth whereas effects on the population are reflected on the economy only in the long-run (Noy, 2009).

Cuaresma, Hlouskova \& Obersteiner (2008) show that countries where the risk of natural disasters is higher tend to receive less knowledge transfers from developed countries. This is an indirect effect of natural disasters. It is quite important to keep in mind that in addition to the direct costs engendered by natural disasters, the indirect costs can be high as well. Investors are more reluctant to invest in regions that are at high risk of natural disasters (Cuaresma, Hlouskova, \& Obersteiner, 2008). Their research also found some evidence of creative destruction following hazards in rich countries.

Loyaza, Olaberria, Rigolini \& Christiansen (2012) also examine the macroeconomic consequences of natural disasters and investigate the question of whether or not disasters bring creative destruction. What they find is that small disasters can have positive growth-effects on some sectors but that major ones do not. They reveal that developing countries suffer more, both in the number of sector affected and by the magnitude of the shocks. In their research, they control for the different types of natural disasters and find that each type affects the sectors of the economy differently. Furthermore, developing and developed countries are not affected identically by each category (Loyaza, Olaberría, Rigolini, \& Christiaensen, 2012). This article brings some very important insights. It shows that in order to have a proper idea of the actual effects of hazards, it is important to differentiate between the different types of disasters and that looking at the sectors of the economy separately show very different results. This would be important when assessing the distributional effects, to know which parts of the population are most affected.

To conclude, researchers have found that whereas disasters can act as creative destruction and foster growth when they are small and when they hit developed countries. Large disasters and disasters hitting developing countries directly reduce GDP growth. In addition, countries at higher hazard exposure tend to receive less knowledge transfer, which is a side effect disasters have on the economy. They also found that in order to observe the exact effects of disasters, one would have to analyze the different types of disasters separately. 


\section{The Effects of Major Natural Disasters}

\subsection{Microeconomic CONSEQUENCES}

In his article, Kristian Jakobsen (2012) examines the microeconomic consequences of the Hurricane Mitch in rural Nicaragua, in 1998. It examines the way natural disasters affect households' income-generating potential. It uses panel data from just before the hurricane until 2001. It uses an asset index to test on the asset losses of the households. He finds that the households were affected at very different severity levels. If on average the hurricane did not significantly affect the ability to generate income, it did have differentiated effects among households. Poorer households were more sensitive to nonproductive asset shocks. Further, inequality increased after the hurricane as poorer households were relatively worse off than richer ones (Jakobsen, 2012).

Dercon, Hoddinott \& Woldehanna (2005) investigated the effects of adverse shocks on consumption in rural Ethiopia. They found that droughts, the most recurrent natural hazard in Ethiopia, had long-lasting effects on the population. Experiencing a drought in the last five years reduced households' consumption by up to $20 \%$. They also found that droughts happening in the 1980s were causally associated with slower growth in the 1990s (Dercon, Hoddinott, \& Woldehanna, 2005). Furthermore, Dercon (2005) argues that risk is an important factor of poverty in African countries. He identifies two types of consequences of risk on poverty. Firstly, the impact shock, which refers to "the event and the coping responses of the households, which may destroy or reduce the physical, financial, human or social capital of the household" (Dercon, 2005). Secondly, the behavioral impact refers to the way households facing risk and with a limited access to insurance have to adopt risk management strategies.

Philippe Auffret (2003) argues that natural disasters affect welfare in three different ways: through physical integrity, assets and income. All three are inter-related. Adverse shocks reduce the physical capital and the human capital available in the economy, which consequently reduces the potential income of the population. He found effects consistent with his theory when analyzing data from countries of the Caribbean and Latin America (Auffret, 2003).

These articles are particularly important to this research as they analyze the effects of natural disasters on the microeconomic level, analyzing what happens to the income and the behavior of the affected households. Jakobsen (2012) and Dercon (2005) findings support the hypothesis that major natural disasters increase inequality by harming the poorest most severely. 


\section{The Effects of Major Natural Disasters}

\section{SAVINGS RATE AND ADVERSE SHOCKS}

The empirical part of the research analyses the effects of hazards on saving rates. It is hence important to first look at what the theory would suggest. The theoretical models of the effects of adverse shocks on the saving behaviors of the population have been analyzed by Skidmore (2001). He claims that protection against losses through disaster insurance is not always available. This inefficiency of the insurance market leads households to self-insure which in turns lead to higher aggregate savings (Skidmore, 2001). He also argues that the likeliness of a loss due to a natural disaster would increase the precautionary saving behavior. Thus, it would make sense to observe an increase in the saving rates in the years following major losses as people adapt their behavior to their past experiences. Furthermore, in the case of important damages, it is also possible that households need to save more following the loss in order to rebuild afterward. This theoretical approach would suggests that after a initial dip in the savings rate due to the immediate shock, it is likely to rise after some time.

\section{THE DATA}

The dataset used for the research is constituted of 13 countries from Asia and Africa. Data on natural disasters come from the CRED database and comprise the number of people reported affected by the natural disaster, the damages in million dollars, and the number of people killed. The data on the savings rate, the GDP growth, the labor market and the exchange rates come from the World Development Indicators (World Bank, 2013). The number of natural disasters reported per country is enormous. Indeed, in order to be registered in the CRED database, a disaster needs to comprise at least of the following criteria: 10 or more people are reported killed; 100 or more people are reported affected; declaration of state emergency; call for international assistance.

The goal of this study is to analyze the effects of major natural disasters. Furthermore, compiling all the reported disasters per year and per country would not have been feasible in an efficient amount of time. Were considered major natural disasters, disasters that had affected at least 100000 people. This estimate was chosen to proxy for the effects of natural disasters as it appeared to be the most reliable and the most consistent one. Furthermore, it was the one least correlated with the level of development of a country. On the one hand, the number of people killed is likely to be greatly reduced by costly preventive measures, hence linked with the GDP of the country; and the damages in million dollars are likely to be greater in more developed 


\section{The Effects of Major Natural Disasters}

countries where there is a larger potential for capital destruction. On the other hand, the number of people affected seems less biased as no matter the level of development of a country, people are still affected, what is most likely to differ is the degree of severity. A dummy was generated using 0 for years without major natural disasters and 1 for years with at least one.

Only developing and underdeveloped countries were considered. Were selected the ones for which reliable and consistent data were available. This seriously limited the database. Thankfully, a large enough database was constituted with data for 16 countries over a 24 year period, from 1988 to 2012.

The savings rate that is used is the gross savings, "calculated as gross national income less total consumption, plus net transfers" (World Development Indicators, 2014). It is expressed in percentage of the GDP.

Table 1 Countries included in

the database

Bangladesh
Cambodia
China
India
Iran
South Korea
Mozambique
Pakistan
Philippines
Sri-Lanka
Sudan
Vietnam
Zambia

\section{Methodology}

The models used in this research are kept very simple. There are two types of models used. First, models using the number of people affected and thus accounting for the severity of the disaster. Second, models using the dummy variable, which differentiate more clearly between years with, and years without major hazards. A panel data analysis is conducted, controlling for 


\section{The Effects of Major Natural Disasters}

heteroskedasticity. The dynamics of the models are taken into consideration in the models. The goal of the research is not to examine the difference between countries but rather the global trend.

Given the small size of the dataset and the intrinsic difficulty of estimating effects of idiosyncratic events along time, it is very tedious to obtain good statistics. Several econometric methods were tested in order to cope with endogeneity and autocorrelation of the variables. Not all tests yielded concluding results. The major results are shown in the paper and interpreted. The two econometric methods used are the Fixed Effects and the Instrument Variables methods. Polynomial distributed lags are used to test the effects of natural disasters over time.

\section{EMPIRICAL ANALYSIS}

The empirics of this research compare two different models, using two different methods. The first model uses the logarithm of the number of people affected as independent variable to explain changes in the savings rate. The second model uses a dummy variable for the occurrence of a major disaster. The results are compared and analyzed.

Running the gross savings against the dummy and 8 of its lags and running a similar regression using the logarithm of the number of people affected and 8 of its lags, one obtains an equation where all explanatory variables are statistically insignificant. However, the R-squared is decently high (slightly higher than 0.30) and the F-statistic highly significant. This is an evidence of collinearity among the regressors. In such cases, the use of Polynomial Distributed Lags (hereinafter PDL) is relevant. Hence, PDL are used in the models.

\section{MODEL WITH NUMBER OF PEOPLE AFFECTED}

This model uses a dummy variable to observe the effects of disasters instead of the number of people affected. This does not reveal anything about the magnitude of the natural disasters but makes the contrast between years with and without major hazards starker.

The following regression was run using the fixed effects model:

$$
\begin{aligned}
& \text { savings }= \\
& \beta_{0}+\beta_{1} \operatorname{PDL}(\log (\text { affected }+1), 5,3)+\beta_{2} \text { gdpgr }+\beta_{3} \text { savings }_{t-1}
\end{aligned}
$$




\section{The Effects of Major Natural Disasters}

With savings for gross savings, affected for number of people affected, gdpgr for GDP growth. In the PDL parenthesis, the " 5 " indicates the number of lag included and the " 3 " indicates the polynomial degree. Table 2 and 3 show the results of this regression using the Fixed Effects Method in Table 2 and the IV Method in Table 3. Only the behavior of log(affected+1) along time is reported, which is the part of the table that is of main interest. The entire tables can be found in the appendix. The instrument variables used to estimate Table 3 are $\operatorname{gdpgr}_{t-1}, \operatorname{gdpgr}_{t-2}$, savings $_{t-2}, P D L(\log ($ affected +1$), 4,3)$.

Table 2 Fixed Effects Method - Number of People Affected Model

\begin{tabular}{c|cccc}
\hline Lag distribution of $\log ($ affected +1$)$ & $i$ & Coefficient & Std. Error & $t$-statistic \\
\hline \hline & 0 & -0.00417 & 0.03627 & -0.11486 \\
& 1 & 0.00431 & 0.01924 & 0.22382 \\
& 2 & 0.00599 & 0.02583 & 0.23187 \\
& 3 & 0.00088 & 0.02451 & 0.03587 \\
& 4 & -0.01102 & 0.02561 & -0.43032 \\
\hline \multirow{2}{*}{ Sum of lags } & -0.00401 & 0.08214 & -0.04885 \\
\hline
\end{tabular}

What one can see from the tables is first of all that the IV Method provides the best result, but even then, they are not really significant. Indeed, the t-statistic of the IV Method is higher than the one of the FE Method. A higher t-value supports the observed behavior of the variable. Both methods show results that are in line with the theory. The interpretations are discussed in the next section. 


\section{The Effects of Major Natural Disasters}

Table 3 Instrument Variables Method - Number of People Affected Model

\begin{tabular}{|c|c|c|c|c|}
\hline Lag distribution of $\log ($ affected +1$)$ & $i$ & Coefficient & Std. Error & t-statistic \\
\hline & 0 & -0.03684 & 0.05107 & -0.72142 \\
\hline & 1 & 0.00827 & 0.02779 & 0.29765 \\
\hline - & 2 & 0.01182 & 0.03661 & 0.32284 \\
\hline & 3 & -0.02621 & 0.03599 & -0.72811 \\
\hline & 4 & -0.10580 & 0.07600 & -1.39223 \\
\hline Sum of lags & & -0.14876 & 0.13128 & -1.13314 \\
\hline
\end{tabular}

One of the pitfalls of this model is that it is quite hard to interpret the effect of a change in the $\log$ affected variable. What it would mean theoretically is that a $1 \%$ increase in the number of people affected would lead to a certain percentage increase in the gross savings. But disasters are unpredictable and idiosyncratic events. The number of people affected may stay at zero for several years before peaking to millions affected for just a year. Thus, a percentage increase does not appear to be the best way to measure the changes. The following model, using a dummy variable, might be more appropriate.

\section{MODEL WITH THE DUMMY VARIABLE}

The model estimated is as follows:

$$
\text { savings }=\beta_{0}+\beta_{1} \operatorname{PDL}(\text { natdis, } 4,2)+\beta_{2} g d p g r+\beta_{3} \text { savings }_{t-1}
$$

Where "natdis" is the dummy variable, taking years without natural disasters as a baseline. The results of the regression using the dummy variable are very similar to the one of the previous model. The IV Method gives better statistics in this model as well. One of the differences in this model is that for the Polynomial Distributed Lag, a quadratic polynomial is used, whereas a thirddegree polynomial was used in the previous model. Both methods show similar diagrams, a negative impact in year 0 , followed by a positive impact for 2 or 3 years and then a negative 


\section{The Effects of Major Natural Disasters}

impact again. Table 4 shows the results using the Fixed Effects Method and table 5 shows the results using the Instrument Variable Method.

Table 4 Fixed Effects Method - Dummy Model

\begin{tabular}{|c|c|c|c|c|}
\hline Lag distribution of the dummy & $i$ & Coefficient & Std. Error & $t$-statistic \\
\hline $\begin{array}{l}1 \\
1\end{array}$ & 0 & -0.07220 & 0.57003 & -0.12665 \\
\hline 1 & 1 & 0.07628 & 0.38160 & 0.19990 \\
\hline \multirow[t]{3}{*}{ । } & 2 & 0.10914 & 0.43317 & 0.25196 \\
\hline & 3 & 0.02638 & 0.38736 & 0.06809 \\
\hline & 4 & -0.17201 & 0.59613 & -0.28855 \\
\hline Sum of lags & & -0.03214 & 1.55494 & -0.02084 \\
\hline
\end{tabular}

Table 5 Instrument Variables Method - Dummy Model

\begin{tabular}{|c|c|c|c|c|}
\hline Lag distribution of the dummy & $\bar{i}$ & Coefficient & Std. Error & $t$-statistic \\
\hline & 0 & -0.59871 & 0.85751 & -0.69819 \\
\hline & 1 & 0.10204 & 0.54788 & 0.18625 \\
\hline & 2 & 0.16404 & 0.63589 & 0.25796 \\
\hline & 3 & -0.41272 & 0.57979 & -0.71184 \\
\hline & 4 & -1.62823 & 1.15976 & -1.40394 \\
\hline Sum of lags & & -2.37358 & 2.40610 & -0.98648 \\
\hline
\end{tabular}




\section{The Effects of Major Natural Disasters}

\section{OTHER MODELS}

Other models were tested using different effects of natural disasters. The damages in million US dollars were used under different forms (log, changes, and real terms) but never appeared as a statistically significant estimator. The number of people killed was also tested as an explanatory variable but never appeared even close to significant. Non-linear models were also tested but none revealed interesting results.

In addition, although not exploitable, OLS regressions were run by curiosity, and even if the coefficients are biased and one cannot draw conclusion from them, their sign were consistent with the theory.

\section{INTERPRETATIONS}

Although the effects might be modest in both models, the actual effect on the affected population might be underestimated. Indeed, the gross savings are calculated for the whole economy whereas natural disasters often hit only a restricted area of the country. Thus the actual effect might be spread out and more difficult to observe at a national level. A regional analysis could lead to a more significant and larger coefficient. The behavior of the savings rate is analyzed in this section.

Both models show similar patterns in the effects of the occurrence of major disasters. This behavior can be interpreted in light of Skidmore's (2001) theoretical approach.

Firstly, right after the event, households need to cope with the damages and suffer from a loss of potential income given the capital destruction. Hence, at first, they dig into their savings to cope with the vital necessities; they have to cut down their savings temporarily. Once they regain their income earning potential, they can start saving more in order to finance the large reconstruction needed. This would explain the positive lag effect one or two years. Once the households have rebuilt the damages, they can reduce their savings rate again to pre disaster levels.

Secondly; another interpretation would be that households adapt their saving behavior following natural disasters. Thus after cutting their savings to handle the reconstruction on the year of the disaster, they adapt their behavior in the following years. Influenced by their passed experience and unable to find insurance at a premium they are willing to pay, households may decide to self-insure and increase their savings. This interpretation is in line with Skidmore's theoretical approach (Skidmore, 2001) but the decrease after 4 or 5 years is not. 


\section{The Effects of Major Natural Disasters}

The interpretations do not exclude one another; it could very well be a combination of both. There is no element in this research that makes it possible to specify clearly which interpretation is most common. Even if the first explanation seems more convincing, determining which one is best is beyond the scope of this paper, some thorough data collection at the household level would be needed in order to lead such investigation.

\section{LIMITATIONS AND DISCUSSION}

The research at hand has a limited scope. Indeed, the dataset is not large enough to draw sound conclusions. A dataset covering more countries, over a longer time span, and with monthly or quarterly data, would make the statistics more reliable. Furthermore, it was arbitrarily decided what to consider a major natural disaster. The cutting point was set at 100000 people affected, one could argue that it would be more appropriate to set it as a percentage of the population. However, this would bring some other issues when considering low-population countries. It is in all cases a very subjective notion and taking a different approach could lead to different results.

In addition, the econometrics used when analyzing are relatively basic, a more thorough analysis, using additional tools or different model estimators would improve the accuracy of the regressions. With a larger database, it would also be interesting to look at the country cases separately in addition to the global trend. And as mentioned earlier, regional rather than national data would be more appropriate, but this is hardly feasible.

Moreover, the research does not show results about the wealth distribution effect of natural hazards. It would be very interesting to compare the effects across different income levels of the population. Some previous case studies found that poorer households are most affected (Jakobsen, 2012), a cross country study could bring interesting conclusions for policy makers about the inequality effect of disasters. 


\section{The Effects of Major Natural Disasters}

\section{Conclusion}

Studying the effects of idiosyncratic events such as natural disasters is a very tedious task, especially when studying developing and underdeveloped countries. This research had to face the scarcity of the data, its infrequency and lack of consistency. This made the statistical analysis difficult. Yet some conclusions can be drawn from the research.

The literature review has shown that disasters affect the populations in many different manners, it also revealed that poor households are likely to suffer more than wealthier ones. Moreover, countries with higher education, higher income, more open economies and more efficient government suffer less from disasters. There is a non-linear relationship between economic losses and the level of development of a country, depending on the degree of hazard exposure.

Although the empirical analysis did not provide statistically significant results, what they reveal is still interesting. It converges with the theoretical approach and shows the dynamics of the effects of natural disasters on the savings rate. Households first suffer from the direct effect and dig into their savings, they than increase their savings rate in order to save money to rebuild what was destroyed or damaged, and after a few years, the savings rate falls again.

What the research has also highlighted is that there is still a vast section of the subject that is yet to study. One of the most interesting questions for policy makers that has not yet been answered, is to know the distributional effect of major natural disasters. A large scale research on the subject would undeniably provide interesting insights. 


\section{The Effects of Major Natural Disasters}

\section{REFERENCES}

Auffret, P. (2003). High Consumption Volatility: The Impact of Natural Disasters? World Bank Policy Working Paper, 2962, 1-33.

Cuaresma, J. C., Hlouskova, J., \& Obersteiner, M. (2008). Natural Disasters as Creative Destruction? Evidence From Developing Countries. Economic Inquiry, 214-226.

Dercon, S. (2005). Risk, Poverty and Vulnerability in Africa. Journal of African Economies, 14(4), 483-488.

Dercon, S., Hoddinott, J., \& Woldehanna, T. (2005). Shocks and Consumption in 15 Ethiopian Villages, 1999-2004. Journal of African Economies, 14(4), 559-585.

EM-DAT. (2009). The EM-DAT Glossary. Retrieved December 29, 2013, from The International Disaster Database: http://www.emdat.be/glossary/9\#letterd

EM-DAT. (2009). World Map. Retrieved December 28, 2013, from The International Disaster Database: http://www.emdat.be/world-map

Greenberg, E. (2008). Introduction to Bayesian Econometrics. Cambridge: Cambridge University Press.

Hoeppe, P. (2008, August 8). The Cost of Climate Insurance for Developing Countries. Retrieved December 28, 2013, from Munich Climate Insurance Initiative: http://www.climate-insurance.org/upload/pdf/Hoeppe_MCII_IRI_side_event.PDF

Jakobsen, K. (2012). In the Eye of the Storm - The Welfare Impacts of a Hurricane. World Development, 40(12), 2578-2589.

Loyaza, N. V., Olaberría, E., Rigolini, J., \& Christiaensen, L. (2012). Natural Disasters and Growth: Going Beyond the Averages. World Development, 40(7), 1317-1336.

Noy, I. (2009). The Macroeconomic Consequences of Disasters. Journal of Development Economics, 221-231.

Padli, J., Habibullah, M. S., \& Baharom, A. H. (2010). Economic Impact of Natural Disasters' Fatalities. International Journal of Social Economics(37), 429-441.

Schumacher, I., \& Strobl, E. (2011). Economic development and losses due to natural disasters: The role of hazard exposure. Ecological Economics, 97-105. 


\section{The Effects of Major Natural Disasters}

Skidmore, M. (2001). Risk, natural disasterss, and household savings in a life cycle model. Japan and the World Economy, 15-34.

Teräsvirta, T. (1980). The Polynomial Distributed Lag Revisited. Empirical Economics, 5, 69-81.

Toya, H., \& Skidmore, M. (2007). Economic Development and the Impacts of Natural Disasters. Economic Letters(94), 20-25.

World Development Indicators. (2014). Retrieved January 5, 2014, from The World Bank: http://databank.worldbank.org/data/views/variableselection/selectvariables.aspx?source= world-development-indicators 


\section{The Effects of Major Natural Disasters}

\section{APPENDIX}

\section{Number of people affected Model:}

\begin{tabular}{|c|c|c|c|c|}
\hline \multicolumn{5}{|c|}{$\begin{array}{l}\text { Dependent Variable: SAVPER } \\
\text { Method: Panel Least Squares } \\
\text { Date: } 01 / 15 / 14 \text { Time: } 11: 24 \\
\text { Sample (adjusted): } 19922012 \\
\text { Periods included: } 21 \\
\text { Cross-sections included: } 14 \\
\text { Total panel (unbalanced) observations: } 259 \\
\text { White cross-section standard errors \& covariance (d.f. corrected) } \\
\text { WARNING: estimated coefficient covariance matrix is of reduced rank }\end{array}$} \\
\hline Variable & Coeff & Std. Error & $\mathrm{t}$-Statistic & Prob. \\
\hline $\begin{array}{c}\text { C } \\
\text { SAVPER }(-1) \\
\text { GDPGR } \\
\text { PDL01 } \\
\text { PDL02 } \\
\text { PDL03 }\end{array}$ & $\begin{array}{r}7.47 \\
0.64 \\
0.25 \\
0.00 \\
-0.00 \\
-0.00\end{array}$ & $\begin{array}{l}1.651751 \\
0.073603 \\
0.102645 \\
0.025825 \\
0.010203 \\
0.009330\end{array}$ & $\begin{array}{r}4.527088 \\
8.761872 \\
2.509491 \\
0.231874 \\
-0.167964 \\
-0.363905\end{array}$ & $\begin{array}{l}0.0000 \\
0.0000 \\
0.0128 \\
0.8169 \\
0.8668 \\
0.7163\end{array}$ \\
\hline \multicolumn{5}{|c|}{ Effects Specification } \\
\hline \multicolumn{5}{|c|}{$\begin{array}{l}\text { Cross-section fixed (dummy variables) } \\
\text { Period fixed (dummy variables) }\end{array}$} \\
\hline $\begin{array}{l}\text { R-squared } \\
\text { Adjusted R-squared } \\
\text { S.E. of regression } \\
\text { Sum squared resid } \\
\text { Log likelihood } \\
\text { F-statistic } \\
\text { Prob(F-statistic) }\end{array}$ & $\begin{array}{r}0.92 \\
0.91 \\
3.32 \\
242 \\
-657 \\
70.2 \\
0.00\end{array}$ & \multicolumn{2}{|c|}{$\begin{array}{l}\text { Mean dependent var } \\
\text { S.D. dependent var } \\
\text { Akaike info criterion } \\
\text { Schwarz criterion } \\
\text { Hannan-Quinn criter. } \\
\text { Durbin-Watson stat }\end{array}$} & $\begin{array}{l}24.52289 \\
11.11712 \\
5.377549 \\
5.913133 \\
5.592886 \\
2.437802\end{array}$ \\
\hline Lag Distribution o & 1 & i Coefficient & Std. Error & t-Statistic \\
\hline \multirow[t]{2}{*}{$\cdot$} & & $\begin{array}{lr}0 & -0.00417 \\
1 & 0.00431 \\
2 & 0.00599 \\
3 & 0.00088 \\
4 & -0.01102\end{array}$ & $\begin{array}{l}0.03627 \\
0.01924 \\
0.02583 \\
0.02451 \\
0.02561\end{array}$ & $\begin{array}{r}-0.11486 \\
0.22382 \\
0.23187 \\
0.03587 \\
-0.43032\end{array}$ \\
\hline & Sum of Lags & -0.00401 & 0.08214 & -0.04885 \\
\hline
\end{tabular}

\begin{tabular}{|c|c|c|c|c|}
\hline \multicolumn{5}{|c|}{$\begin{array}{l}\text { Dependent Variable: SAVPER_- } \\
\text { Method: Panel Two-Stage Least Squares } \\
\text { Date: 01/14/14 Time: } 14: 06 \\
\text { Sample (adjusted): } 19922012 \\
\text { Periods included: } 21 \\
\text { Cross-sections included: } 14 \\
\text { Total panel (unbalanced) observations: } 255 \\
\text { White cross-section standard errors \& covariance (d.f. corrected) } \\
\text { Instrument specification: C GDPGR (-1) GDPGR (-2) SAVPER (-2) PDL(* } \\
\text { Constant added to instrument list }\end{array}$} \\
\hline Variable & Coeffi & Std. Error & t-Statistic & Prob. \\
\hline $\begin{array}{l}\text { C } \\
\text { SAVPER_(-1) } \\
\text { GDPGR } \\
\text { PDL01 } \\
\text { PDL02 } \\
\text { PDL03 } \\
\end{array}$ & $\begin{array}{r}-0.13 \\
0.68 \\
1.52 \\
0.01 \\
-0.01 \\
-0.02\end{array}$ & $\begin{array}{l}2.538344 \\
0.105398 \\
0.696430 \\
0.036606 \\
0.018947 \\
0.018429 \\
\end{array}$ & $\begin{array}{r}-0.051663 \\
6.501084 \\
2.186660 \\
0.322839 \\
-0.909943 \\
-1.127865 \\
\end{array}$ & $\begin{array}{l}0.9588 \\
0.0000 \\
0.0297 \\
0.7471 \\
0.3638 \\
0.2605 \\
\end{array}$ \\
\hline \multicolumn{5}{|c|}{ Effects Specification } \\
\hline \multicolumn{5}{|c|}{ Cross-section fixed (dummy variables) } \\
\hline $\begin{array}{l}\text { R-squared } \\
\text { Adjusted R-squared } \\
\text { S.E. of regression } \\
\text { F-statistic } \\
\text { Prob(F-statistic) } \\
\text { Instrument rank }\end{array}$ & $\begin{array}{l}0.82 \\
0.80 \\
4.83 \\
105 \\
0.00\end{array}$ & \multicolumn{2}{|c|}{$\begin{array}{l}\text { Mean dependent var } \\
\text { S.D. dependent var } \\
\text { Sum squared resid } \\
\text { Durbin-Watson stat } \\
\text { Second-Stage SSR } \\
\text { Prob(J-statistic) }\end{array}$} & $\begin{array}{l}24.64266 \\
10.99232 \\
5519.117 \\
2.258993 \\
3381.926 \\
0.444190\end{array}$ \\
\hline Lag Distribution & F1_ & Coefficient & Std. Error & t-Statistic \\
\hline & i & $\begin{array}{r}-0.03684 \\
0.00827 \\
0.01182 \\
-0.02621 \\
-0.10580\end{array}$ & $\begin{array}{l}0.05107 \\
0.02779 \\
0.03661 \\
0.03599 \\
0.07600\end{array}$ & $\begin{array}{r}-0.72142 \\
0.29765 \\
0.32284 \\
-0.72811 \\
-1.39223\end{array}$ \\
\hline & nol & -0.14876 & 0.13128 & -1.13314 \\
\hline
\end{tabular}




\section{The Effects of Major Natural Disasters}

\section{Dummy Variable Model:}

\begin{tabular}{|c|c|c|c|c|}
\hline \multicolumn{5}{|c|}{$\begin{array}{l}\text { Dependent Variable: SAVPER_- } \\
\text { Method: Panel Least Squares } \\
\text { Date: 01/13/14 Time: } 20: 54 \\
\text { Sample (adjusted): } 19922012 \\
\text { Periods included: } 21 \\
\text { Cross-sections included: } 14 \\
\text { Total panel (unbalanced) observations: } 259\end{array}$} \\
\hline Variable & Coeffic & Std. Error & t-Statistic & Prob. \\
\hline $\begin{array}{c}\text { C } \\
\text { GDPGR } \\
\text { SAVPER }(-1) \\
\text { PDL01 } \\
\text { PDL02 } \\
\text { PDL03 }\end{array}$ & $\begin{array}{r}7.468 \\
0.257 \\
0.644 \\
0.109 \\
-0.024 \\
-0.057\end{array}$ & $\begin{array}{l}1.360692 \\
0.089053 \\
0.049607 \\
0.433168 \\
0.177867 \\
0.161172\end{array}$ & $\begin{array}{r}5.488634 \\
2.892926 \\
12.99879 \\
0.251960 \\
-0.140298 \\
-0.358695\end{array}$ & $\begin{array}{l}0.0000 \\
0.0042 \\
0.0000 \\
0.8013 \\
0.8886 \\
0.7202\end{array}$ \\
\hline \multicolumn{5}{|c|}{ Effects Specification } \\
\hline \multicolumn{5}{|c|}{$\begin{array}{l}\text { Cross-section fixed (dummy variables) } \\
\text { Period fixed (dummy variables) }\end{array}$} \\
\hline $\begin{array}{l}\text { R-squared } \\
\text { Adjusted R-squared } \\
\text { S.E. of regression } \\
\text { Sum squared resid } \\
\text { Log likelihood } \\
\text { F-statistic } \\
\text { Prob(F-statistic) }\end{array}$ & $\begin{array}{r}0.923 \\
0.910 \\
3.322 \\
2428 \\
-657.3 \\
70.21 \\
0.000\end{array}$ & $\begin{array}{l}\text { Mean depe } \\
\text { S.D. depen } \\
\text { Akaike info } \\
\text { Schwarz cri } \\
\text { Hannan-Qu } \\
\text { Durbin-Wat }\end{array}$ & $\begin{array}{l}\text { dent var } \\
\text { lent var } \\
\text { criterion } \\
\text { erion } \\
\text { nn criter. } \\
\text { on stat }\end{array}$ & $\begin{array}{l}24.52289 \\
11.11712 \\
5.377417 \\
5.913002 \\
5.592754 \\
2.438163\end{array}$ \\
\hline \multicolumn{2}{|c|}{ Lag Distribution of DUMAFF } & Coefficient & Std. Error & t-Statistic \\
\hline 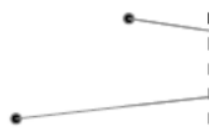 & & $\begin{array}{r}-0.07220 \\
0.07628 \\
0.10914 \\
0.02638 \\
-0.17201\end{array}$ & $\begin{array}{l}0.57003 \\
0.38160 \\
0.43317 \\
0.38736 \\
0.59613\end{array}$ & $\begin{array}{r}-0.12665 \\
0.19990 \\
0.25196 \\
0.06809 \\
-0.28855\end{array}$ \\
\hline & m of & -0.03241 & 1.55494 & -0.02084 \\
\hline
\end{tabular}

\begin{tabular}{|c|c|c|c|c|}
\hline \multicolumn{5}{|c|}{$\begin{array}{l}\text { Dependent Variable: SAVPER_- } \\
\text { Method: Panel Two-Stage Least Squares } \\
\text { Date: 01/14/14 Time: 09:35 } \\
\text { Sample (adjusted): } 19922012 \\
\text { Periods included: } 21 \\
\text { Cross-sections included: } 14 \\
\text { Total panel (unbalanced) observations: } 255 \\
\text { Instrument specification: C GDPGR_(-1) GDPGR_(-2) SAVPER_(-2) } \\
\quad \text { PDL(DUMAFF }, 4,2 \text { ) } \\
\text { Constant added to instrument list }\end{array}$} \\
\hline Variable & Coefficient & Std. Error & t-Statistic & Prob. \\
\hline $\begin{array}{c}\text { C } \\
\text { GDPGR } \\
\text { SAVPER }(-1) \\
\text { PDL01 } \\
\text { PDL02 } \\
\text { PDL03 } \\
\end{array}$ & $\begin{array}{r}-0.140490 \\
1.536991 \\
0.682188 \\
0.164036 \\
-0.257381 \\
-0.319376 \\
\end{array}$ & $\begin{array}{l}2.710125 \\
0.627754 \\
0.103335 \\
0.635886 \\
0.286215 \\
0.285856\end{array}$ & $\begin{array}{r}-0.0 \\
2.4 \\
6.6 \\
0.2 \\
-0.8 \\
-1.1\end{array}$ & $\begin{array}{l}0.9587 \\
0.0151 \\
0.0000 \\
0.7967 \\
0.3694 \\
0.2650\end{array}$ \\
\hline \multicolumn{5}{|c|}{ Effects Specification } \\
\hline \multicolumn{5}{|c|}{ Cross-section fixed (dummy variables) } \\
\hline $\begin{array}{l}\text { R-squared } \\
\text { Adjusted R-squared } \\
\text { S.E. of regression } \\
\text { F-statistic } \\
\text { Prob(F-statistic) } \\
\text { Instrument rank }\end{array}$ & $\begin{array}{r}0.818382 \\
0.804529 \\
4.859931 \\
105.8719 \\
0.000000 \\
20\end{array}$ & \multicolumn{2}{|c|}{$\begin{array}{l}\text { Mean dependent var } \\
\text { S.D. dependent var } \\
\text { Sum squared resid } \\
\text { Durbin-Watson stat } \\
\text { Second-Stage SSR } \\
\text { Prob(J-statistic) }\end{array}$} & $\begin{array}{l}24.64266 \\
10.99232 \\
5574.067 \\
2.253031 \\
3381.949 \\
0.443199\end{array}$ \\
\hline \multicolumn{2}{|c|}{ Lag Distribution of DUMAFF_ } & Coefficient & Std. Error & t-Statistic \\
\hline & $\int_{1}^{1}$ & $\begin{array}{r}-0.59871 \\
0.10204 \\
0.16404 \\
-0.41272 \\
-1.62823\end{array}$ & $\begin{array}{l}0.85751 \\
0.54788 \\
0.63589 \\
0.57979 \\
1.15976\end{array}$ & $\begin{array}{r}-0.69819 \\
0.18625 \\
0.25796 \\
-0.71184 \\
-1.40394\end{array}$ \\
\hline & m of Lags & -2.37358 & 2.40610 & -0.98648 \\
\hline
\end{tabular}

